Eberstein" (the names are imaginary). I gave him my name in return. After a minute or two the second man got up: "My name is Goldschmidt." I gave him my name. When the third man got up I fortunately remembered that I had a trump card to play, and after he had gone through his ritual I replied, "My name is Dr. Schuster," laying stress on the title. Whereupon all three silently left in a body. My degree was a suffi- cient distinction in rank to justify me in dispensing with the formality of asking for an introduction to them. I asked my friend what would have happened if I had not been a graduate: his reply was, that I should have had either to fight at least one duel or been treated as an outcast by German universities. All this happened fifty years ago, and must not be considered to apply to the present day.

\title{
Obituary.
}

Sir James Mackenzie, F.R.S.

$\mathrm{B}^{\mathrm{Y}}$ $\mathrm{Y}$ the death of Sir James Mackenzie the medical profession and the world at large has lost a physician whose life was devoted to the advancement of our knowledge of practical medicine. His researches on diseases of the heart effected nothing less than a revolution in this branch of medicine, which had been stagnant for nearly a century.

Sir James Mackenzie was born at Scone in 1853 , and received his medical education at the University of Edinburgh, where he graduated in 1878 . After extending his training by resident appointments in the Royal Infirmary he took his M.D. in r882. Then followed twenty-eight years of busy general practice in Burnley, and it was during these years that he made the greater part of the observations which made his fame. It soon struck him, as it must strike many medical men, that for the diagnosis and treatment of a vast proportion of illness, his teachers had been unable to give him anything like adequate guidance. Mackenzie, greatly stirred by discontent, set himself to the filling of some of the gaps, and two examples of this pioneer work may be mentioned. The value of pain as a guide to diagnosis was realised when he found that it was referred from the offending organ to particular areas of the surface of the body through the agency of the nervous system, and that the organ was not itself painful. This fundamental change in the conception of pain was independently discovered and extended by Dr. Henry Head. Another gap so brilliantly, almost completely filled, was the classification of the irregularities of the heart. For this purpose Mackenzie invented a clinical polygraph for recording not only the pulse but also simultaneously the venous pulse in the neck. It thus became possible for the first time to observe the action of the auricle, which proved a key to the elucidation of arrhythmia. Irregularities and murmurs were shown to be significant or insignificant by the rational, though laborious, method of following cases exhibiting them for years until their degree of importance became manifest.

Great interest was aroused at home and abroad by the immediate value of these discoveries, and when Mackenzie relinquished his general practice at Burnley in 1907 to take up consulting work in London, he was recognised as the foremost investigator and authority in the world on heart disease. His popularity as a consultant was not allowed to interfere with research, which was continued first at the Mount Vernon Hospital and later at the London Hospital. The action of digitalis in disease was studied to such purpose that, as Prof. Cushny has said, "more progress was made in fifteen years than in the preceding century." The impetus of progress was given to disciples from all over the world, and to them were opened fields of thought and work which seem sufficient for a generation.

When the War came, Mackenzie initiated through the War Office a special hospital for the elucidation of problems connected with "soldier's heart." In I9I8 he retired from consulting work and went to St. Andrews, where he founded the Institute for Clinical Research. $\mathrm{He}$ had realised that attention was habitually directed to fully developed disease, so that, as he said, patients seemed to be admitted to hospital when they had the physical signs of obvious disease and might almost be described as incurable. He determined to study afresh the nature of symptoms as met with in practice, so as to learn of disease in its early and perhaps curable stage. As time went on, he foresaw that the phenomena of disease might be governed by simple laws which he formulated as a basis for further examination by his colleagues at the Institute. Then his health failed, but not his faith and courage, and he finally retired to London, where he died on January 26.

Mackenzie's personal qualities were an ornament to the greatness and originality of his mind, and endeared him to all his pupils. He was indefatigable himself, an inspiring and generous master, a superman, but none was more human. His personality will remain as worthy of admiration as was his relentless pursuit of knowledge, not only for its own sake but also for its application in the relief of suffering humanity.

In I9I I Mackenzie was appointed physician to the cardiac department of the London Hospital. In $19 \times 5$ he became a fellow of the Royal Society, and received the honour of knighthood; later he was appointed honorary consulting physician to the King in Scotland. His most important works are "The Study of the Pulse "(I902), " Diseases of the Heart " (I908), "Symptoms and their Interpretation" (r909), "Principles of Diagnosis and Treatment in Heart Affections " (I9I6), and "Angina Pectoris" (I923).

\section{Mr. William Watson}

WE regret to announce the death of Mr. William Watson, which occurred at St. Albans on January $3 \circ$. $\mathrm{He}$ was well known in botanical and horticultural circles through his long tenure of the curatorship of the Royal Botanic Gardens, Kew, a position he held from August r9or until June I922.

Mr. Watson was born at Garston, near Liverpool, on March $1_{3}, 1858$, and received his first appointment at Kew in 1879 , following several years' experience in trade establishments. His knowledge of tropical and sub-tropical plants was probably unrivalled. For many years he was a regular contributor to the

$$
\text { No. } 2886 \text {, voL. I I 5] }
$$


horticultural press, and so long ago as the eighties of last century wrote a valuable series of articles on the Palmaceæ in the Gardener's Chronicle. These articles it was hoped might have been republished in book form as a monograph of this natural order, thereby bringing Berthold Seemann's work on the same family up-to-date. This hope, however, was never fulfilled. To vol. I5 of the Annals of Botany he contributed an illustrated paper " On the germination of Bertholletia excelsa," the Brazil nut.

In later years Watson took a keen interest in the Cactaceæ and succulent plants generally, and his "Cactus Culture for Amateurs" is the standard work on its subject. He also wrote books on "Climbing Plants," "Rhododendrons and Azaleas," and, in collaboration with W. J. Bean, "Orchids, their Culture and Management," all of which met with success. On horticulturists in general he conferred a great boon by editing a new edition of "Thompson's Gardener's Assistant," so much improving it that it became practically a new work. For upwards of twenty years he was editor of the garden section of the Field. His life's work, however, was centred in Kew, an institution which owes very much to his forty-three years' devoted service. $\mathrm{He}$ was elected an associate of the Linnean Society in 1904 .

THE Chemiker-Zeitung reports the death on January 6 , at the age of sixty-eight, of Dr. Wilhelm Borchers, professor of metallurgy and electrometallurgy at the
Technische Hochschule of Aix-la-Chapelle. Borchers was born at the university town of Erlangen, and after completing his studies there, he spent the next four years in a chemical factory as process chemist. The experience thus gained was of immense value to him in his later career as an investigator, for it enabled him to bring to a successful conclusion many difficult researches in the field of electrometallurgy. In $189 \mathrm{r}$ he was appointed lecturer in chemistry and metallurgy at Duisburg, and six years later he was transferred to the Hochschule at Aix-la-Chapelle. His chief interest lay in the application of electrolytic processes to metallurgical problems, such as the production of metallic calcium, strontium, titanium, cerium, etc. He also conducted numerous researches on the preparation and properties of alloys. Prof. Borchers was the author of several books on electrochemistry, and in 1894 he founded the Zeitschrift für Elektrochemie, which he edited until Igoo. He also collaborated with Nernst in publishing the Jahrbuch der Elektrochemie.

WE regret to announce the following deaths :

Prof. Walther Dieckmann, of the Department of Chemistry in the University of Munich, on January I2, whilst cairying out a research in organic chemistry in the State laboratory.

Miss Lilian Suzette Gibbs, known for her work on the mountain flora of Australasia and on problems relating to the geographical distribution of plants.

Dr. E. E. Klein, F.R.S., formerly lecturer on advanced bacteriology in the Medical School, St. Bartholomew's Hospital, on February 9, aged eighty.

\section{Current Topics and Events.}

INTEREST in the therapeutics of consumption has again been roused by the reports of successful treatment, this time by a chemotherapeutic agent which, under the name of sanocrysin, has been investigated by Møllgaard, a professor in the Landbohojskole of Copenhagen. There is no mystery chemically about sanocrysin. It is sodium aurous thiosulphate $\left(\mathrm{Na}_{3} \mathrm{Au}\left(\mathrm{S}_{2} \mathrm{O}_{3}\right)_{2}\right)$ which has long been known as Fordos and Geles salt. Years ago it was shown that gold salts have a powerful action on tubercle bacilli in vitro and several gold preparations, simple and complex, have been tried therapeutically with indifferent success. Møllgaard affirms that sanocrysin inhibits the growth of tubercle bacilli in a dilution of $\mathrm{I}: \mathrm{I}, 000,000$ and that their progress may be completely arrested in a concentration of $\mathrm{I}$ : I00,000. In non-tuberculous animals sanocrysin is said to be relatively harmless, whereas in tuberculous subjects very stormy reactions follow its exhibition and may actually end in death. It is believed by M $\phi$ llgaard that these violent effects are to be attributed to certain poisons, of a tuberculin character, which are liberated from the dying and dead tubercle bacilli from the action of the sanocrysin rather than to a direct toxic action of the thiosulphate. It is said that the violent reactions can be lessened or prevented by the administration of an anti-serum produced by the injection of tubercle bacilli or its products. The sanocrysin treatment is really a twofold process. There is supposed to be the direct bactericidal action of sanocrysin and the neutralisa- tion of its poisonous results by an antitoxin of sorts. The Møllgaard treatment has been applied for a considerable time both in cases of tuberculous human beings and animals, but judgment must at present be reserved as to whether it is likely to occupy a permanent place in tuberculo-therapy.

IN the course of his fourth talk on "Ether and Reality " given under the auspices of the British Broadcasting Company at the London station, 2LO, on February 17, Sir Oliver Lodge discussed magnetism and its analogies with life and knowledge. Sir Oliver stated that electrification is a matter of transfer, a transfer of pre-existent charges, a disturbance of equilibrium. When equilibrium is established, opposite charges are close together and disappear from our ken. They never go out of existence: we neither create nor destroy. The same is true for magnetism : we can make a magnet, but the magnetism was there beforehand. Magnetic lines of force differ from electric lines in being always closed loops ; all we do is to open them out. They tend to shrink, and thereby pull together two things round which they are looped, like an indiarubber ring. They never shrink up to nothingness. One magnet can produce any number of others, for there is no limit to the amount of magnetisation; what one body gains, the other does not lose. In that respect it is analogous with life. Knowledge in this respect is like life and magnetism: there is an unlimited reservoir from NO. 2886, VOL. I I 5 ] 